\title{
Olanzapine-associated hypothermia: a case report of a rare event
}

\author{
Manuel Monti, Valeria Mommi, Maria Beatrice Forte, Francesco Paciullo, Francesca Francavilla, \\ Francesco Borgognoni
}

Emergency Department, Local Health Unit Umbria 1, Assisi (PG), Italy

\begin{abstract}
Hypothermia, a potentially fatal condition, is defined as a drop of the body temperature below $35^{\circ} \mathrm{C}$. The most common cause of severe hypothermia is the environmental exposure to low-temperatures. Other causes include septicemia, diabetic ketoacidosis, trauma, acute spinal cord injury, prolonged cardiac arrest and hypothyroidism. The hypothermia is an infrequent, but previously documented, adverse effect of antipsychotic medications. A 83-year-old Italian woman was transported to the Emergency Room with a reduced level of consciousness, Glasgow coma scale 7. She was bradycardic (heart rate 42 bpm), $80 / 150 \mathrm{mmHg}$ blood pressure and respiratory rate $26 / \mathrm{min}$. Her physical examination was significant for an anal temperature of $31^{\circ} \mathrm{C}$. Blood exam and chest X-ray were unremarkable. In her clinical history, she was suffering from generalized anxiety disorder for the last 2 years and was prescribed olanzapine $7.5 \mathrm{mg}$ daily. In recent days, the patient experienced a cognitive impairment with heat intolerance and had been reduced the dose of olanzapine $5 \mathrm{mg}$ daily. On the basis of the clinical findings, the patient's body temperature and blood exam, the diagnosis of olanzapine-associated hypothermia was made. The patient was gradually rewarmed with blankets and warm saline infusion and the olanzapine therapy was discontinued. She gradually regained consciousness after $18 \mathrm{~h}$ and, after 1 day, the patient's body temperature increased up to $37.8^{\circ} \mathrm{C}$ with an improvement of the neurological conditions. We reported about the case of a patient treated with stable doses of olanzapine for a long period of time that developed hypothermia, a potentially fatal complication. This case shows that it is important to consider every change in the patient behavior, e.g., the poor resistance to heat present in our patient, that should exhibit warning sign of hypothermia.
\end{abstract}

\section{Introduction}

Thermoregulation occurs in the preoptic area of the anterior hypothalamus and the hypothermia is defined as a state in which the body's mechanism for regulating the temperature is altered. ${ }^{1}$

Hypothermia is defined as a decline in core temperature below $35^{\circ} \mathrm{C}$. Hypothermia can be classified as mild (core body temperature: $32.0^{\circ} \mathrm{C}$ to $<35.0^{\circ} \mathrm{C}$ ),

Correspondence: Manuel Monti, USL UMBRIA1 U.O.

PS/118, via V. Muller 1, 06081 Assisi (PG), Italy.

E-mail:montimanuel@tiscali.it

Key words: Antipsychotics; hypothermia; medication effects; olanzapine.

Conflict of interest: the authors declare no potential conflict of interest.

Received for publication: 8 October 2017.

Revision received: 3 December 2017.

Accepted for publication: 29 January 2018

This work is licensed under a Creative Commons Attribution NonCommercial 4.0 License (CC BY-NC 4.0).

(C) Copyright M. Monti et al., 2018

Licensee PAGEPress, Italy

Italian Journal of Medicine 2018; 12:67-69

doi:10.4081/itjm.2018.937 moderate $\left(28.0^{\circ} \mathrm{C}\right.$ to $<32.2^{\circ} \mathrm{C}$ ), or severe (below $\left.28.0^{\circ} \mathrm{C}\right) .{ }^{2,3}$

The mechanisms that contribute to mortality depend on the metabolic changes. These modifications cause acidosis, changes in the plasma $\mathrm{Ca} 2+$, and the clearance of magnesium and potassium from the cells to the extracellular space. At the level of the heart, this causes a decreased depolarization of cardiac pacemaker cells with consequent bradycardia and ventricular arrhythmias. ${ }^{4,5}$

Furthermore, hypothermia progressively reduces the metabolism of the central nervous system because there is a decrease in the consumption of oxygen that is linear with respect to the temperature reduction. ${ }^{5} \mathrm{In}$ the absence of medical disorders that alter the temperature regulation control system, unintentional hypothermia is caused by environmental exposure. ${ }^{6}$ Secondary hypothermia results when a disease state interferes with thermoregulation through interference of any of the multiple pathways that maintain heat balance (such as a medical illness lowering the temperature set-point or a major trauma). ${ }^{7}$ Although hyperthermia is more commonly linked to antipsychotics, profound hypothermia may also occur. ${ }^{8}$

\section{Case Report}

An 83-year-old Italian woman was transported to the emergency room with a reduced level of con- 
sciousness, Glasgow coma scale 7. She opened her eyes to verbal response, and she was able to localize pain. She was bradycardic (heart rate $42 \mathrm{bpm}$ ), her blood pressure was $80 / 150 \mathrm{mmHg}$ and respiratory rate 26/min. The patient had normal heart and breath sounds. Abdomen, and musculoskeletal examinations were unremarkable. Her physical examination was significant for an anal temperature of $30.9^{\circ} \mathrm{C}$. At the time of admission, the electrocardiogram showed sinus bradycardia with $\mathrm{J}$ waves. The thyroid-stimulating hormone level was $2.2 \mathrm{mU} / \mathrm{L}$ and free thyroxin level was $2.8 \mathrm{u} / \mathrm{dL}$. Random and early morning cortisol levels were checked and also were within normal limits (Table 1).

Current medications at admission: omeprazole 20 mg once a day, hydrochlorothiazide/amiloride $25 / 5$ $\mathrm{mg}$ once a day, acetylsalicylic acid $75 \mathrm{mg}$, alprazolam $0.25 \mathrm{mg}$ twice daily, olanzapine $7.5 \mathrm{mg}$ daily. She was a widow and lived with her daughter. In her clinical history, she was suffering from generalized anxiety disorder for the last 2 years and was prescribed olanzapine $7.5 \mathrm{mg}$ daily for two years. On the days before the event, the patient experienced a cognitive impairment with heat intolerance and had been reduced the dose of olanzapine $5 \mathrm{mg}$ daily. On the basis of the clinical findings, the patient's body temperature and electrocardiogram findings, the diagnosis of hypothermia was made (Figure 1). The patient did not have any risk factors for developing hypothermia except for the use of olanzapine.

Table 1. Patient's main serum chemistry values.

\begin{tabular}{lcc}
\hline Laboratory data & Numerical value (SI units) & Normal range values \\
\hline $\mathrm{Hb}$ & $115 \mathrm{~g} / \mathrm{L}$ & $120-160 \mathrm{~g} / \mathrm{L}$ \\
\hline $\mathrm{MCV}$ & $93.5 \mathrm{fL}$ & $81-99 \mathrm{fL}$ \\
\hline $\mathrm{MCHC}$ & $350 \mathrm{~g} / \mathrm{L}$ & $330-370 \mathrm{~g} / \mathrm{L}$ \\
\hline $\mathrm{PLT}$ & $1.75 \times 10^{9} / \mathrm{L}$ & $130-400 \times 10^{9} / \mathrm{L}$ \\
\hline $\mathrm{WBC}$ & $9.1 \times 10^{9} / \mathrm{L}$ & $4.8-10.8 \times 10^{9} / \mathrm{L}$ \\
\hline $\mathrm{TSH}$ & $2.2 \mathrm{mU} / \mathrm{L}$ & $0.4-5.0 \mathrm{mU} / \mathrm{L}$ \\
\hline Sodium & $137 \mathrm{mEq} / \mathrm{L}$ & $132-143 \mathrm{mEq} / \mathrm{L}$ \\
\hline Potassium & $4,4 \mathrm{mEq} / \mathrm{L}$ & $3.5-5.8 \mathrm{mEq} / \mathrm{L}$ \\
\hline Troponin I & $0 \mu \mathrm{g} / \mathrm{mL}$ & $<1.5 \mu \mathrm{g} / \mathrm{mL}$ \\
\hline Free T4 & $10.2 \mathrm{pmol} / \mathrm{L}$ & $8.5-15.2 \mathrm{pmol} / \mathrm{L}$ \\
\hline C-reactive protein & $6.7 \mathrm{mg} / \mathrm{L}$ & $<5 \mathrm{mg} / \mathrm{L}$ \\
\hline Creatinine & $105 \mu \mathrm{mol} / \mathrm{L}$ & $<115 \mu \mathrm{mol} / \mathrm{L}$
\end{tabular}

$\mathrm{Hb}$, hemoglobin; MCV, mean corpuscular volume; MCHC, mean corpuscular hemoglobin concentration; PLT, platelets; WBC, white blood cells; LDH, lactate dehydrogenase; TSH, thyroid-stimulating hormone; free $\mathrm{T} 4$, free thyroxine.

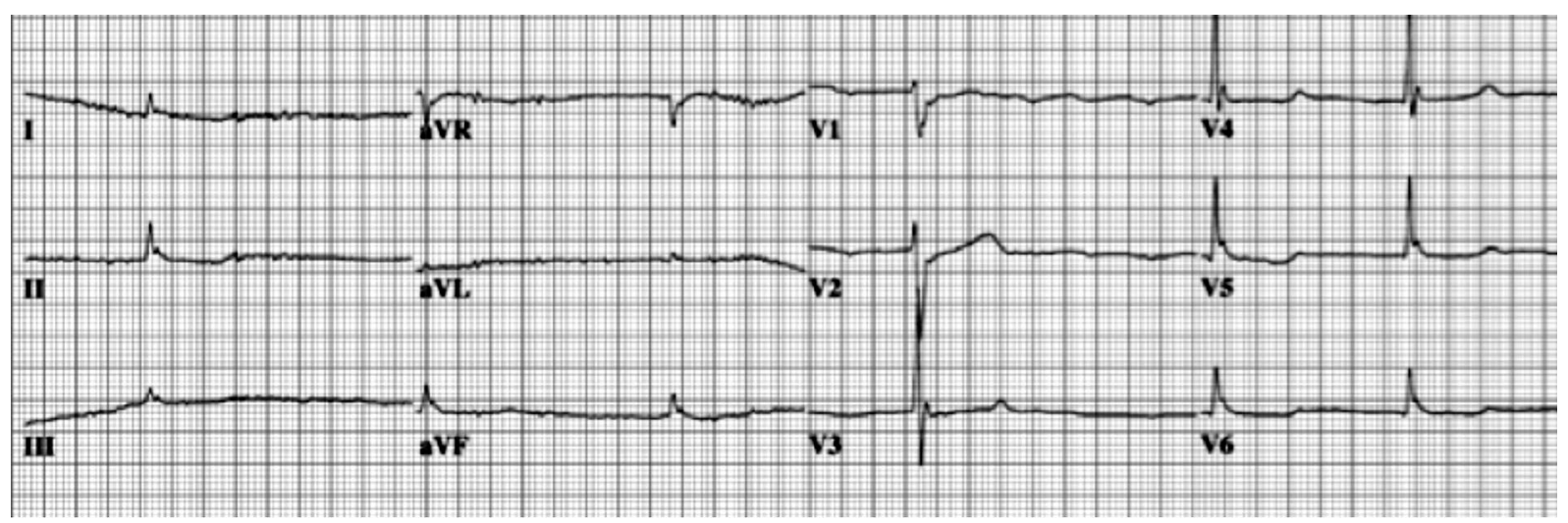

Figure 1. Electrocardiogram showing bradycardia and the presence of the $\mathbf{J}$ wave. 
She was rewarmed gradually with warmed saline intravenous solutions, washing with warm fluids through nasogastric tube and urinary catheter, and external heating by thermal blanket. The olanzapine was discontinued. She gradually regained consciousness after $18 \mathrm{~h}$. After clinical improvement, the patient's body temperature was $37.8^{\circ} \mathrm{C}$ and we witnessed an overall improvement of her neurological conditions.

\section{Discussion}

Hypothermia has long been a dangerous complication of antipsychotic drug therapy. The most common antipsychotic drug associated with hypothermia is risperidone. ${ }^{9}$ Olanzapine is an a-typical antipsychotic drug. In normal conditions, dopaminergic and serotonin receptor activity, which decrease and increase body temperature, respectively, are balanced. Mainly, olanzapine has a higher affinity for $5-\mathrm{HT}_{2}$ serotonin receptors than $\mathrm{D}_{2}$ dopamine receptors and this is responsible for a deterioration of this balance, and this increases the risk of developing hypothermia. ${ }^{10,11}$

Also, olanzapine increases the concentrations of neurotensin. ${ }^{12}$ Neurotensin is present at high concentrations in the hypothalamus and has been recognized as an important mediator of hypothermia. The increase of the neurotensin facilitates the development of hypothermia. ${ }^{12}$

\section{Conclusions}

Based on the findings in our patient and from the data from literature, we hypothesize that the patient developed hypothermia due to olanzapine.

This indicates that, when we are faced with a patient with hypothermia, a careful history should be done and we must consider antipsychotics a potential cause of hypothermia, particularly in the elderly with recent behavioral changes.

\section{References}

1. Kreuzer P, Landgrebe M, Wittmann M, et al. Hypothermia associated with antipsychotic drug use: a clinical case series and review of current literature. J Clin Pharmacol 2012;52:1090-7.

2. Vanden Hoek TL, Morrison LJ, Shuster M, et al. Part 12: Cardiac arrest in special situations. Circulation 2010;122:S829-61.

3. Lazar HL. The treatment of hypothermia. N Engl J Med 1997;337:1545-7.

4. Jeican II. The pathophysiological mechanisms of the onset of death through accidental hypothermia and the presentation of "The little match girl" case. Clujul Med 2014;87:54-60.

5. Kempainen RR, Brunette DD. The evaluation and management of accidental hypothermia. Respir Care 2004;49:192-205.

6. Wong KC. Physiology and pharmacology of hypothermia. West J Med 1983;138:227-32.

7. Søreide K. Clinical and translational aspects of hypothermia in major trauma patients: from pathophysiology to prevention, prognosis and potential preservation. Injury 2014;45:647-54.

8. Parris C, Mack JM, Cochiolo JA, et al. Hypothermia in 2 patients treated with atypical antipsychotic medication. J Clin Psychiatry 2001;62:61-3.

9. Schwaninger M, Weisbrod M, Schwab S, et al. Hypothermia induced by atypical neuroleptics. Clin Neuropharmacol 1998;21:344-6.

10. Rasnayake LR, Wimalarathne H, Jayapala RK, et al. An unusual case of hypothermia associated with therapeutic doses of olanzapine: a case report. J Med Case Rep 2011;5:189.

11. Kansagra A, Patel S, Wilcox SR. Prolonged hypothermia due to olanzapine in the setting of renal failure: a case report and review of the literature. Ther Adv Psychopharmacol 2013;3:335-9.

12. Sharma RP, Janicak PG, Bissette G, Nemeroff CB. CSF neurotensin concentrations and antipsychotic treatment in schizophrenia and schizoaffective disorder. Am J Psychiatry 1997;154:1019-21. 